The New Port Moresby $\alpha<\alpha<\alpha<\alpha<\alpha<\alpha<\alpha<\alpha<\alpha<\alpha<\alpha<<<<$ 


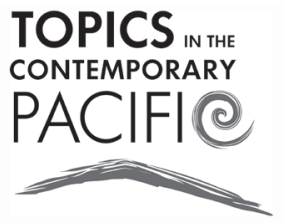

Brij V. Lal Jack Corbett

General Editors 


\section{The New Port Moresby}

Gender, Space, and Belonging in

Urban Papua New Guinea

Ceridwen Spark

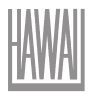

University of Hawai'i Press

Honolulu 
(C) 2020 University of Hawai'i Press

All rights reserved

Printed in the United States of America

\section{Library of Congress Cataloging-in-Publication Data}

Names: Spark, Ceridwen, author.

Title: The new Port Moresby : gender, space, and belonging in urban Papua New Guinea / Ceridwen Spark.

Other titles: Topics in the contemporary Pacific.

Description: Honolulu : University of Hawai'i Press, 2020. | Series: Topics

in the contemporary Pacific | Includes bibliographical references and index.

Identifiers: LCCN 2020007875 | ISBN 9780824881801 (cloth) | ISBN

9780824882792 (pdf) | ISBN 9780824882815 (epub) | ISBN 9780824882808

(kindle edition)

Subjects: LCSH: Women-Papua New Guinea-Port Moresby-Social

conditions-Case studies. | Port Moresby (Papua New Guinea)—Social conditions.

Classification: LCC HQ1866.5.Z9 S63 2020 | DDC 305.409953—dc23

LC record available at https://lccn.loc.gov/2020007875

Cover art: Female hotel staff await plane arrivals at Jackson's

Airport in the weeks before APEC 2018. Photo courtesy of the author.

University of Hawai'i Press books are printed on acid-free paper and meet the guidelines for permanence and durability of the Council on Library Resources. 
To my parents, Raymond and Helen Spark, who made PNG my first home. Thank you for being adventurers. 
